FOKUS

Jurnal Kajian Keislaman

dan Kemasyarakatan
Institut Agama Islam Negeri (IAIN) Curup, Indonesia

ISSN 2548-334X (p); 2548-3358 (e)

volume 6, number 2, 2021 | page: 171-192

DOI: http://doi.org/10.29240/jf.v6i2.3412

\title{
Konsep Mubadalah Faqihuddin Abdul Kodir dan Formulasinya dalam Pola Pengasuhan Anak
}

\author{
M. Afiqul Adib', Natacia Mujahidah ${ }^{2}$ \\ ${ }^{1}$ UIN Sunan Kalijaga Yogyakarta, ${ }^{1}$ UIN Sunan Kalijaga Yogyakarta \\ 1afiquladib@gmail.com; mujahidahnatacia17@gmail.com
}

\begin{abstract}
The concept of mubadalah (mutuality) is the most logical choice in an equal relationship. In its development, this concept does not only apply to a husband and wife relationship but can also be between parents and children. Parenting is an important factor in the development of a child's potential. Therefore, choosing a parenting style that upholds gender equality will more or less reduce inequality between men and women. The purpose of this research is to formulate the concept of mublah in parenting. This research is a literature research that uses a qualitative approach with data collection methods of observation, interviews, and documentation. Data analysis used critical descriptive analysis technique. These results indicate that the concept of mubdalam can be applied in parenting, because it is very useful in shaping the character of children in the future so that they view humans as equals. The application of the concept of mublah in parenting can be described as a process of cooperation between fathers and mothers in raising children. Not delegating work and responsibilities to one another. In addition, the potential of girls can also be developed to the fullest
\end{abstract}

Keywords: Mubadalah concept, Parenting pattern

Abstrak. Konsep mubadalah (kesalingan) hadir menjadi pilihan paling logis dalam sebuah hubungan yang setara. Dalam perkembangannya, konsep ini tidak hanya berlaku untuk sebuah hubungan suami istri saja, melainkan bisa juga antara orang tua dan anak. Pola asuh menjadi faktor penting dalam pengembangan potensi seorang anak. Oleh sebab itu, pemilihan pola asuh yang menjunjung tinggi kesetaraan gender, sedikit banyak akan mengurangi ketimpangan antara laki-laki dan perempuan. Tujuan penelitian ini adalah memformulasikan konsep mubadalah dalam pola asuh anak. Penelitian ini adalah penelitian pustaka yang menggunakan pendekatan kualitatif dengan metode pengumpulan data observasi, interview, dan dokumentasi. Analisis data menggunakan Teknik analisis deskriptif secara kritis. Hasil penelitian ini menunjukkan bahwa konsep mubadalah dapat diterapkan dalam pola asuh anak, karena sangat berguna dalam membentuk karakter anak di kemudian hari 
agar memandang manusia secara setara. Penerapan konsep mubadalah dalam pola pengasuhan anak dapat diuraikan sebagai proses kerja sama antara ayah dan ibu dalam mengasuh anak. Tidak saling melimpahkan pekerjaan dan tanggung jawab pada satu sama lain. Selain itu, potensi anak perempuan juga dapat dikembangkan secara maksimal.

Keywords: Konsep Mubadalah, Pola Asuh Anak.

\section{Pendahuluan}

Pembicaraan tentang gender sangat umum terjadi, namun masih saja sering terjadi kesalahpahaman tentang pengertian konsep gender. Kesalahpahaman ini tidak sekadar ada pada sebagian kecil orang, melainkan ada pada golongan masyarakat akademisi. ${ }^{1}$ Kata gender tidak jarang dikacaukan menggunakan kata sex atau jenis kelamin, dan merujuk pada perempuan. Padahal kata "gender" seharusnya bukan saja dilekatkan bersama wanita, melainkan juga pria.

Sex dan gender ini pada dasarnya memiliki perbedaan yang esensial. Sex secara sederhana hanya menyangkut tentang aspek biologi saja. Namun, gender lebih luas, yakni menyangkut hal-hal apa saja yang membawahi aspek biologi tersebut dalam lingkup atau pandangan masyarakat. Mansour Fakih mengemukakan bahwa gender merupakan karakteristik bawaan manusia, dan dikonstruksi dalam masyarakat dan budaya. ${ }^{2}$ Selama tidak menimbulkan kesenjangan antara laki-laki dan perempuan, yang berujung pada ketidakadilan dan pembedaan perlakuan, terutama bagi perempuan. Ketidaksetaraan masyarakat dalam memandang wanita menyebabkan ketidaksamaan perlakuan dalam berbagai hal, seperti pemanfaatan kekuasaan, perundungan, kekerasan seksual, dan perlakuan-perlakuan yang menjurus pada ketidakadilan. ${ }^{3}$ Jika masyarakat percaya kalau wanita tidak lebih tinggi daripada pria, serta anggapan kalau wanita hanyalah pengurus rumah, maka gender akan bisa dianggap sebagai permasalahan. Jika sosial percaya kalau upah wanita dan kompensasi atas pekerjaannya dianggap tidak lebih tinggi daripada pria, maka gender juga menjadi masalah, karena perempuan "hanya" pencari nafkah tambahan. Serta jika posisi publik perempuan harus lebih rendah dari laki-laki,

\footnotetext{
${ }^{1}$ Faqihuddin Abdul Kodir, Qiraah Mubadalah (Yogyakarta: IRCiSoD, 2019).

2 Mansor Fakih, Analisis Gender Dan Transformasi Sosial (Yogyakarta: Insist

${ }^{3}$ Ibid.
} Press, 2020). 
maka gender akan menjadi masalah karena perempuan memiliki sifat feminin, tidak bisa memimpin, kurang mandiri, dan sebagainya. 4

Jenis pemisahan orientasi seksual telah muncul di masa muda. Wanita sering menjadi korban kebiadaban dalam pengaturan. Romantisme adalah perilaku atau aktivitas individu dalam pemujaan (pacaran) ketika salah satu pihak merasa terkekang, apa yang dilakukan, dan dirugikan oleh apa yang dilakukan komplotannya. 5 Langkah penting untuk dipertimbangkan ketika membahas tema gender yakni mulai berusaha membaca dengan lengkap sesuai dengan fakta dan bukti penelitian yang sesuai, tidak seakadar satu sudut pandang atau hegemoni patriarki semata. Tema gender ini memanglah merupakan produk pemikiran modern, di mana semangat kebebasan memegang peran yang sangat mendesak. Namun, ketika disejajarkan dengan Islam seakan-akan tidak bisa disatukan dengan harmonis. Ini menjadi tidak logis, karena keselarasan gender dalam perspektif Islami merupakan keutuhan. Tentu saja hal tersebut akan terjadi jika memang dilakukan kajian yang objektif dan menyeluruh. ${ }^{6}$ Dalam Islam terdapat beberapa permasalahan gender. Lebih tepatnya bukan dari Islam melainkan dari tafsiran ayat-ayat Alquran. Banyak mufasir tekstual percaya bahwa Alquran memberi pria lebih banyak hak daripada wanita. Berbeda dengan mufasir kontekstual yang percaya bahwa konsep tafsir gender dijaman nabi diperlukan tafsir baru untuk menyesuaikan kondisi saat ini, yang mana bertujuan menghapus ketidaksetaraan tersebut. ${ }^{7}$

Lahirnya Islam merupakan salah satu cara untuk menyelesaikan permasalahan yang dihadapi umat manusia. Terutama kedatangan Nabi Muhammad SAW dimaksudkan untuk mengajari masyarakat Jahiliyah agar tidak lagi membunuh anak-anak yang tidak bersalah. Anak perempuan harus dihormati dan diberi hak untuk hidup seperti laki-laki. Jika ada beberapa norma dalam sebuah siklus sosial yang jauh dari ingar-bingar keadilan, maka pandangan tersebut jangan sampai diterima. Pasalnya, jika kita melakukan penelitian lebih mendalam, ternyata Alquran maupun sunah tidak bisa

${ }^{4}$ Ismi Dwi Astuti Nurhaeni, Kebijakan Publik Pro Gender (Surakarta: LPP UNS Dan UNS Press, 2009).

5 Boediarsih Boediarsih, Zahroh Shaluhiyah, and Syamsulhuda Budi Mustofa, "Persepsi Remaja Tentang Peran Gender Dan Gender Seksualitas Di Kota Semarang," Jurnal Promosi Kesehatan Indonesia 11, no. 1 (2016).

6 Taufan Anggoro, “Konsep Kesetaraan Gender Dalam Islam,” Afkaruna 15, no. 1 (2019).

${ }^{7}$ Abdullah Saeed, Al-Qur'an Abad 21; Tafsir Kontekstual, Terjemahan. (Bandung: Mizan, 2016). 
sembarangan memperlakukan perempuan. Hubungan antar umat Islam didasarkan pada prinsip persamaan dan persaudaraan. ${ }^{8}$

Salah satu standar Islam adalah antara orang, negara, klan dan kerabat. Kontras antara satu ciptaan tuhan dengan lainnya hanya sebuah ketaqwaan. Banyak bagian dari Al-Qur'an menunjukkan bahwa orang memiliki kebanggaan yang sama sebagai individu. Seperti yang diungkapkan dalam Al-Qur'an surat an-Nahl: 97, dan Q.S. al- Mujadillah, 58: 11: Agar terjadi kesetaraan terhadap semua jenis gender, maka seyogyanya kaum muslim yang taat mulai belajar dan memahami tafsir Alquran dan hadis secara lebih komprehensif. Banyak ayat Alquran dan sunah yang menunjukkan bahwa perempuan memiliki kemampuan untuk aktif dalam berbagai pekerjaan. Oleh karena itu, keadilan gender merupakan kondisi yang ideal dan adil bagi laki-laki dan perempuan.

Kemajuan penting yang harus dipertimbangkan dalam tema ini adalah untuk benar-benar memahaminya berdasarkan informasi dan bukti terkait. Bukan hanya didasarkan pada kesepakatan yang tidak lengkap dan tampak idealis. Keseimbangan orientasi seksual tidak diragukan lagi merupakan hasil pemikiran masa kini, di mana jiwa peluang mengambil pekerjaan yang sangat mendesak. Meskipun demikian, begitulah dengan Islam, atau bahkan bertentangan dengan Islam, tampaknya ada hambatan tinggi yang signifikan antara keduanya. ${ }^{9}$

Memang, bila dilihat lebih seksama, gagasan tentang orientasi seksual dan Islam itu sendiri dapat saling berhubungan satu sama lain. Dengan syarat, jiwa objektivitas dan bantuan ilmu-ilmu terkait yang dimiliki dalam penyelidikan faktual. Karena banyak hal yang perlu dibenahi di bidang gender, banyak cendekiawan Islam yang menggaungkan isu tersebut, salah satunya adalah Faqihuddin Abdul Kodir adalah.

Beliau merupakan salah satu cendekiawan yang membawa kemungkinan pembebasan perempuan Islam, atau diurutkan sebagai aktivis perempuan lakilaki yang tidak berdaya melawan perempuan. Komitmennya di bidang ini mulai terlihat pada tahun 1999. Sudah lama ia dinamis dalam bakti sosial Islam untuk kemajuan daerah, khususnya penguatan perempuan. ${ }^{10}$ Kalau ditelisik, ketertarikan beliau bisa dilihat dari disertasi yang membahas tentang hadis sebagai pendukung dalam pewujudan keadilan wanita. Beliau juga aktif mengajar di IAIN Syekh Nurjati Cirebon, ISIF Cirebon, serta di Pondok

8 Badriyah Fayumi, Marzani Anwar, and Siti Musdah Mulia, Keadilan Dan Kesetaraan Gender Persepektif Islam (Jakarta: Tim Pemberdayaan Perempuan Bidang Agama, 2001).

${ }^{9}$ Anggoro, "Konsep Kesetaraan Gender Dalam Islam."

${ }^{10}$ Kodir, Qiraah Mubadalah. 
Pesantren Kebon Jambu al-Islami Babakan Ciwaringin, dan berfokus dengan hal-hal tentang pembebasan hak-hak perempuan serta kesalingan antara makhluk. ${ }^{11}$

Sejak tahun 2001 beliau telah menulis artikel kajian hadis tentang isu pemberdayaan perempuan di nomor 39 dari 53 nomor majalah swara Rahima yang telah terbit sampai tahun 2015. Dalam tulisan tersebut beliau masih menggunakan istilah 'kesalingan' dan 'timbal balik'. Baru di nomor tulisan ke 40 yang terbit pada desember 2012, istilah mubadalah diperkenalkan karena sesuai dengan teks dalam Alquran. Inti dari tulisan-tulisan tersebut membincang tentang salah satu tantangan serius terhadap usaha mewujudkan keadilan gender adalah mengubah paradigma kesetaraan antara laki-laki dan perempuan. Sehingga salah satu pihak memiliki sentimen untuk menguasai pihak lain agar tidak ditaklukkan terlebih dahulu

Sejak 2016, beliau diberikan kepercayaan menjadi bagian dari pemuatan buku, penasihat, dan pemberi fasilitas instruktur "Bimbingan Perkawinan", kegiatan ini digawangi oleh Kementrian Agama Republik Indonesia, yang lebih fokus pada penguatan kemampuan calon pengantin untuk mewujudkankeluarga sakinah yang bertumpu pada relasi kesalingan, kemitraan dan kerja sama. Di tahun tersebut juga beliau mulai menulis dan menginisiai pembuatan blog bertema keadilan gender sesuai pandangan Islam melalui www.mubadalah.com. ${ }^{12}$

Kang Faqih (panggilan akrabnya) merupakan cendekiawan muda yang selalu resah dengan temuan di lapangan yang mengungkapkan banyaknya kasus perundungan atas wanita yang terjadi secara tidak putus-putus. Ironinya, fenomena tersebut semakin kuat karena kesalahan penafsiran agama. Kegelisahan tersebut membuat beliau mencari konsep, metode dan pendekatan yang sesuai untuk menjawab permasalahan yang ada. Qiraah mubadalah merupakan konsep yang beliau hadirkan untuk menjawab kegelisahan tersebut. Konsep kesetaraan gender beliau tawarkan dengan konsep mubadalah atau kesalingan. Karena bagi beliau kesetaraan gender dimaksudkan sebagai dasar penciptaan suatu konsep relasi wanita dan pria. Qiraah mubadahal adalah sumbangan pemikiran yang ilmiah dan mudah dipraktikkan dalam kehidupan bermasyarakat baik di rumah tangga maupun di ruang publik.

Artikel yang ditulis ini menggunakan library research, yakni memperoleh data dari perbukuan atau literatur terkait, kemudian melakukan analisis

\footnotetext{
11 Ibid.

12 Ibid.
} 
filosofis teoritis, menarik kesimpulan dan menentukan relevansinya. Penelitian ini pada dasarnya adalah penelitian analisis deskriptif, mencoba mendeskripsikan gagasan Faqihuddin Abdul Kodir tentang kesetaraan gender dan rumusannya dalam pola asuh anak.

Kemudian melakukan penyajian data, yang bisa berupa bagan, kategori atau sejenisnya yang dapat mempermudah peneliti dalam memahami kejadian yang kemudian peneliti akan merencanakan kegiatan selanjutnya untuk perkembangan proses penelitian. Dan terakhir adalah penarikan kesimpulan dan verifikasi atas penelitian yang dilaksanakan.

\section{Hasil dan Pembahasan}

\section{Konsep Mubadalah}

Faqihuddin Abdul Kodir yang akrab disapa Kang Faqih merupakan cendekiawan muslim yang rajin menyuarakan ketidakadilan gender. Dalam diskursus tersebut, beliau menawarkan konsep yang dinamai mubadalah atau diartikan sebagai kesalingan. Mubadalah lebih lanjut berkembang dalam pandangan tertentu, tentang sebuah konsep saling paham dalam berhubungan yang memegang prinsip setara, saling, sama, dan hal lainnya yang sejenis..$^{13}$ Kesalingan tersebut tidak terbatas pada suami istri saja, melainkan lebih luas antara berbagai status sosial seperti anak dan orang tua, guru dan murid, mahasiswa dan dosen, dan sebagainya.

Hubungan kesetaraan ini mempertegas pernyataan bahwa tidak ada posisi yang lebih tinggi dalam sebuah kemitraan, dan tidak dibenarkan merasa lebih tinggi atau melakukan kedzaliman, hegemoni, serta tindakan asusila dengan mendominasi satu dengan lainnya. Karena tugas manusia diciptakan yakni menjadi pengelola dunia, karena hal tersebut untuk mensukseskan tugas tersebut dibutuhkan kerja sama atau kesalingan antara laki-laki dan perempuan.

Diksi “Mubadalah" berasal dari bahasa Arab yang memiliki arti mengganti, mengubah, menukar, menggilir, tukar menukar, dan makna seputar timbal balik. Kemudian dalam bahasa Indonesia, istilah mubadalah dapat dimaknai sebagai kesamaan antara laki-laki dan perempuan, dalam arti keduanya masing-masing saling diuntungkan. ${ }^{14}$

${ }^{13}$ Ibid.

${ }^{14}$ Anisah Dwi Lestari P, "Qira ' Ah Mubadalah Dan Arah Kemajuan Tafsir Adil Gender: Aplikasi Prinsip Resiprositas Terhadap Alquran Surah Ali Imran: 14," Muasarah: Jurnal Kajian Islam KOntemporer 2, no. 1 (2020). 
Mubadalah fokus pada senyum itu, keramahan, administrasi, dan semua pekerjaan yang menyenangkan yang harus dilakukan oleh seorang pasangan kepada pasangannya, begitu juga seorang istri kepada pasangannya. Pedoman muballah (gotong royong) dalam penerapannya mencakup semua kualitas dan standar keadilan dan kemanusiaan. Keseimbangan dan umat manusia adalah dua pendirian penting untuk mengakui keuntungan, kebaikan, dan kesetaraan.

Dengan standar ini, pria yang perlu dianggap apa adanya, keputusannya, suaranya didengar, dan setiap keinginannya dipuaskan, wanita adalah sesuatu yang serupa. Wanita juga memiliki hak untuk dilihat, didengarkan keputusannya, didengar suaranya, dan dipuaskan keinginannya.15 Sudut pandang yang sama ini akan menciptakan pandangan yang memurnikan orang. Suatu pandangan yang mendorong hubungan yang setara dan sepadan bagi perempuan, yang hidup di tengah masyarakat sebagai arus kas untuk melaksanakan bantuan pemerintah terhadap laki-laki dan masyarakat umum.

Hal ini sependapat dengan Nur Rofi'ah, yang dikutip Taufan Anggoro, menegaskan bahwa mubâdala adalah pandangan tentang hubungan antar manusia yang bersifat organisasi dan kerjasama. Organisasi di antara orangorang di sini luas, yang tujuannya adalah keuntungan dari keberadaan manusia. Teknik ini secara praktis mencoba untuk menyelidiki signifikansi teks (AlQur'an dan hadits) dengan tujuan agar cenderung diterapkan pada semua jenis orang secara bersamaan. Lebih lanjut, ia menjelaskan, jika sebuah teks hanya membahas satu orientasi seksual, diperlukan penyelidikan yang lebih mendalam untuk mendapatkan implikasi yang dapat diterapkan pada keduanya. ${ }^{16}$

Mubadalah sangat sesuai dengan prinsip kesetaraan gender, terutama dalam bidang pendidikan, yakni: Pertama, Memiliki kesamaan penerimaan sekolah, misalnya, semua jenis kelamin berhak mendapatkan kesempatan dan jangkauan yang setara dalam suatu pembelajaran yang berlangsung. Karena sangat kurang bijak jika faktor jenis kelamin dijadikan alasan menyelewengkan hak mereka untuk mendapatkan layanan pendidikan. Kedua, Mubadalah juga menjauhi konsep bahwa perempuan hanya cocok untuk dapur sehingga tidak memerlukan sekolah dengan tingkat yang tinggi.

Komitmen serupa, contohnya, semua jenis kelamin berhak mendapatkan komitmen untuk mencari informasi. Sesuai dengan hadits nabi, berpendidikan adalah suatu hal yang wajib ditunaikan dengan paripurna oleh orang Islam. Ketiga, Kesetaraan posisi dan pekerjaan, misalnya, semua jenis orang memiliki

15 Wilis Werdiningsih, "Penerapan Konsep Mubadalah Dalam Pola Pengasuhan Anak," Ijougs: Indonesian Journal of Gender Studies 1, no. 1 (2020).

16 Anggoro, "Konsep Kesetaraan Gender Dalam Islam." 
situasi yang sama sebagai subjek atau penghibur perbaikan. Situasi semua jenis orang sebagai subjek perbaikan memainkan peran yang sama dalam mengatur, melaksanakan, mengamati dan mengambil bagian dalam konsekuensi kemajuan. Akhirnya diidentifikasi dengan ekuitas kesempatan. ${ }^{17}$

Kecenderungan gender memiliki dampak yang kurang baik bagi remaja putra, maupun putri. Ada tuntutan sosiologis bagi mereka untuk selalu bertingkah laku seperti stereotipe atau konstruksi dalam masyarakat umum. Seperti, remaja putri harus berpenampilan menawan, tidak kasar, serta melayani. Sedangkan remaja putra harus tegar, kuat, tak kenal takut, dan sebagainya. Hal ini akan mempengaruhi bagaimana kehidupan mereka di lingkungan sosial, serta pekerjaan di kemudian hari.

Kemungkinan mubadalah adalah untuk menjamin keadilan dan kesetaraan dalam hubungan di antara orang-orang, dan untuk mendorong adanya kolaborasi partisipatif, wajar dan menguntungkan bagi keduanya tanpa segregasi. Ruang publik tidak hanya diharapkan untuk pria, sementara ruang rumahan tidak hanya dipaksakan pada wanita. Ketertarikan pada publik dan lokal harus tersedia dengan cara terbesar yang dapat dibayangkan untuk semua jenis orang dengan cara yang sama. ${ }^{18}$

Jadi konsep mubadalah menurut Faqihuddin Abdul Kodir adalah prinsip berhubungan antara laki-laki dan perempuan secara setara atau kesalingan yang tidak hanya hubungan antara suami istri saja, melainkan secara luas dalam semua konstruksi sosial, seperti pelajar dan guru, anak dan orang tua, dan sebagainya. Karena dalam Islam juga ditegaskan bahwa ang membedakan antara laki-laki dan perempuan adalah keimanan, bukan jenis kelaminnya, maka tidak dibenarkan dalam tindakan apapun untuk saling mendominasi atas dasar jenis kelamin.

\section{Pola Pengasuhanan Anak}

Hasil wawancara dengan beberapa narasumber, yakni beberapa mahasiswa dan salah satu dosen PRODI PAI sekaligus dosen pembimbing program tahfidz yang ada di lingkungan UIN Raden Fatah Palembang. Berikut hasil wawancara kami dengan narasumber, salah satunya dosen Prodi PAI

Pola asuh adalah konsep hubungan yang terjadi dalam keluarga, yakni hubungan anak-anak bersama orang tuanya seperti bagaimana cara orang bersikap dan berinteraksi kepada anak, cara mereka menetapkan aturan,

17 Warni Tune Sumar, "Ilmplementasi Kesetaraan Gender Dalam Bidang Pendidikan," MUSAWA 7, no. 1 (2015).

18 Werdiningsih, "Penerapan Konsep Mubadalah Dalam Pola Pengasuhan Anak." 
mengajarkan nilai ataupun norma, memberikan kasih sayang dan perhatian serta bagaimana cara mereka bersikap sehingga dijadikan panutan bagi anakanak mereka. sedangkan menurut agama Islam pola pengasuhan anak secara tersirat dijelaskan dalam QS al-Baqarah ayat 20 tentang panduan mengasuh atau memberikan perlakuan yang selaras dengan agama Islam, yakni membuat pemahaman tentang anak tidak dalam satu aspek saja, selain itu juga penerapan atau ushwah yang baik kepada anak dalam banyak hal, seperti bagaimana memperlakukan anak yatim, bagaimana berbuat baik, melindungi, melakukan pemeliharaan, merawat, dan bagaimana memberikan rasa sayang dengan saksama.

Pola pengasuhan anak berkaitan erat dengan upaya keluarga dalam pemberian rasa nyaman, seperti: selalu ada, support, komunikasi yang baik kepada anak yang masih dalam masa-masa pertumbuhan. ${ }^{19}$ Pola pengasuhan ini adalah tahapan yang bertujuan dalam rangka pendukung pengembangan fisik, emosi, empati, finansial dan kecerdasan anak yang dimulai semenjak anak tersebut lahir kedunia hingga ia dewasa. Orang tua menjadi penanggung jawab dalam berbagai hal tersebut sebab keduanya adalah orang pertama yang mengajari berbagai macam pengethauan yang sifatnya teori maupun praktis. ${ }^{20}$

Dari pemaparan tersebut maka diketahui bahwa pola asuh merupakan suatu metode bagi orang tua untuk bertindak memberikan pendidikan serta perlindungan kepada anak-anaknya tersebut, dimulai dari bayi hingga anak tersebut beranjak dewasa. Peran ayah dan ibu di sini sangat vital, maka dari itu pola pengasuhan anak sangat berkaitan erat dengan peran kekeluargaan dalam rumah terkait dengan penyampaian emosi dan empati, serta hal-halyang sifatnya praktis

Dalam sudut pandang anak, keluarga berperan sebagai tempat pertama yang mereka miliki untuk belajar, bertumbuh dan berkembang. Jika anak merasakan suasana yang hangat, nyaman, dan tentram dalam keluarga, besar kemungkinan seorang individu akan bertumbuh secara positif. Hubungan baik yang terjalani antara anak dan orang tua memainkan peran penting dalam melahirkan kepekaan moral tertentu dalam diri seseorang. Individu yang hidup dan berkembang dalam kasih sayang yang cukup akan tumbuh sebagai individu yang memiliki kestabilan emosi.21

${ }^{19}$ Istina Rakhmawati, "Peran Keluarga Dalam Pengasuhan Anak," KONSELING RELIGI: Jurnal Bimbingan Konseling Islam 6 (2015).

${ }^{20}$ Sitti Nur Aidah, Tips Menjadi Orang Tua Inspirasi Masa Kini (Yogyakarta: KKM Indonesia, 2020).

${ }^{21}$ Herviana Muarifah Ngewa, "Peran Orang Tua Dalam Pengasuhan Anak," Ya Bunayya 1 (2019). 
Maka dari itu pemilihan pola asuh dengan baik, akan berdampak dalam tumbuh kembang serta perilaku anak. Anak-anak cederung meniru kebiasaan orang-orang disekitarnya. Hubungan yang kuat antara anak dan orang tua dapat terbentuk dari pola pengasuhan yang bersifat intens dari kedua oran tua, ataupun anak dengan orang yang mengasuhnya. Pola pengasuhan menjadi satu hal yang krusial karena dapat membantu pembentukan karakter, moralitas, pengetahuan, keterampilan, dan berbagai aspek lain pada diri anak teresbut. Tiap-tiap orang tua berhak untuk memilih konsep pengembangan parenting yang sesuai dengan kebutuhannya. Ada 3 jenis pola asuh yang biasanya dipakai dalam parenting, diantaranya:

a. Pola asuh permisif.

Model ini merupakan jenis yang memberi ruang dan waktu secara lebih terbuka bagi anak. Anak dibebaskan untuk melakukan apapun susuka hatinya. Di satu sisi, orang tua tidak terlalu peduli dengan perkembangan anak. Orang tua cenderung memberikan amanah mengasuh anak kepada Yayasan, atau Lembaga lainnya. Jenis model ini bisa berdampak buruk menjadikan sesorang yang memiliki sifat egois, sebab orang tua memiliki kecenderungan membebaskan dan memanjakan anak. Keegoisan tersebut dapat menjadi dinding yang mengahlangi hubungan anatara anak dan orang lain dalam bermasyarakat. ${ }^{22}$

b. Pola asuh otoriter.

Model ini biasanya digunakan oleh orang tua yang biasanya berasal dari pengalaman dan trauma masa kecilnya yang menerima jenis perlakuan serupa. Pola asuh ini tidak ada ruang dialog untuk anak. Sederhanya, peraturan dibuat agar dapat mengontrol anak. Tidak hanya sampai disitu, beberapa bahkan menggunakan model ini secara keras dengan dalih untuk pendidikan.

Orang tua seringkali memberi cengkraman yang keras terhadap segala tindakan anak, dengan kata lain anak harus menurut pada orang tua, jika melanggar maka anak akan mendapatkan sanksi berupa hukuman yang tak jarang berupa hukuman fisik yang menurut para ahli dapat berakit buruk pada fisik dan mental anak tersebut. Di antara dampak mentalnya yakni anak menjadi tidak percaya diri, memiliki sifat agresif, dan pemalu. Sifat agresif tersebut timbul sebab kemarahan,

\footnotetext{
22 M Sahlah Syafie, Bagaimana Anda Mendidik Anak (Bogor: Ghalia Indonesia,
} 2002). 
perilaku destruktif, serta hal-hal kurang positif lainnya yang menumpuk. ${ }^{23}$

Terlepas dari hal tersebut mungkin orang tua dapat mengkombinasikan berbagai jenis pola asuh. Adapun pendapat para ahli pola pengasuhan otoriter ini dapat memberikan beberapa dampak pada anak, misalnya: labil atau kesulitan dalam urusan pilihan karena ada ketakutan, trauma, serta susah untuk menolak atau memberikan penolakan, ketakutan berpendapat, dan sebagainya. ${ }^{24}$

Menurut Hemat penulis, individu yang sejak dini memiliki khidupan dengan campur tangan orang lain cenderung kurang bahagia, serta tidak memiliki kewarasan mental secara memadai. Dampak kedepannya serupa seseorang yang telah ditinggalkan oleh orang terdekatnya. Untuk beberapa keadaan pola asuh ini mungkin dapat diterapkan. Menurut para ahli, pola asuh ini dapat disesuaikan terhadap individu yang bermasalah dengan perilaku tertentu, misalnya untuk mengatur jam malam.

c. Pola Asuh Autoritatif

Jenis pengasuhan ini adalah gaya pengasuhan yang paling disarankan untuk wali. Karena dalam pengasuhan ini ada batasan dan konsistensi yang jelas pada anak-anak. Pola asuh ini juga tidak menggunakan kekerasan. Orang tua memberi ruang untuk anak-anak berdiskusi. Seperti memberi pengertian mengapa orang tua menerapkan peraturan tertentu untuk mereka.

Singkatnya, pengasuhan semacam ini tidak membebaskan anak untuk bergerak, tetapi ia menganggapnya cocok untuk mengendalikan anak secara tidak perlu. Sangat menarik bahwa wali memberikan kebebasan kepada anak-anak untuk memilih dan bertanggung jawab atas keputusan mereka. Pola asuh ini berdampak positif, misalnya anak memiliki kemampuan sosial yang hebat, pandai mengurus masalah, bisa bekerja sama dengan orang lain, lebih pasti, ternyata lebih inovatif. ${ }^{25}$

d. Pola asuh demokratis

Konsep ini merupakan pola asuh yang lebih menomersatukan sudut pandang anak. Jadi, kebebasan untuk berkreasi dan mengeksplor banyak hal tetap diberikan oleh orang tua. Pola pengasuhan ini menunjukan kematangan ibu dan bapaknya sebagai orang tua dalam

\footnotetext{
${ }^{23}$ Aidah, Tips Menjadi Orang Tua Inspirasi Masa Kini.

24 Ibid.

25 Ibid.
} 
mengasuh, tidak menuntut apapun dan memberikan bimbingan kepada anak sesuai dengan kondisi dan situasi.

Konsep ini juga meningkatkan bonding antara semua pihak keluarga. Kebebasan yang didapatkan anak pada pola asuh ini bukan berarti tanpa aturan sama sekali, orang tua tetap memberikan aturan dan batasan tertentu terhadap apa saja hal-hal yang diperbolehkan atau tidak, agar anak tetap berapa pada jalur yang benar. Ada beberapa gambaran orang tua dengan pola asuh demokrasi diantaranya Pertama tidak menuntut anak, dalam artian orang tua tidak mengharapkan sesuatu yang melebihi kemampuan anak.

Mereka menghargai dan paham kalau tiapindividu mempunyai skill yang khas, dan tidak sama dengan yang lain. Kedua, memberikan pengertian dalam artian anak bebas memilih apa yang mereka sukai namun orang tua tetap memberikan aturan sebagai rambu, jadi setiap anak melakukan kesalan, ia sadar akan konsekuensi atas kesalahannya tanpa perlu merasa terkekang. ${ }^{26}$

Dari beberapa konsep yang telah dijabarkan di atas, maka menurut hemat penulis, pola asuh demokratis merupakan pola asuh yang sejalan dengan konsep mubadalah yang dipaparkan oleh Faqihudin Abdul Kodir. Hal ini dikarenakan dalam pola asuh demokratis ini para orang tua lebih menghargai dan paham jika anak memiliki keterampilan masing-masing tanpa membedakan jenis kelaminnya. Anak dibebaskan memilih sesuai dengan apa yang mereka suka, meski tetap saja ada rambu-rambu yang harus dipatuhi.

Pola asuh ini tidak bertentangan dengan konsep mubadalah atau kesalingan, yang memang tidak memandang individu berdasarkan jenis kelaminnya, tetapi berdasarkan potensi yang dimiliki dan harus dikembangkan. Sehingga orang tua memiliki kewajiban untuk mendiskusikan dengan anak secara setara, sesuai apa yang dibutuhan anak, bukan sesuai dengan ego orang tua terhadap anak. Keluarga merupakan lingkungan paling pertama yang dimiliki oleh anak, segala perkembangan dan tingkah laku pada anak merupakan hasil dari meniru orang tuanya. Selain itu, sebagai pihak yang bertanggung jawab dalam pendidikan anak mereka, orang tua memiliki pengaruh yang sangat besar terhadap pekembangan pendidikan anak. ${ }^{27}$

Keluarga memiliki peran yang penting sebab keluarga adalah pondasi utama bagi anak dalam mempelajari banyak hal. Peran orang tua merupakan

26 Ibid.

${ }^{27}$ Anik Twiningsih and Fepi Trimurni H, Ayah Terlibat Keluarga Hebat (Jurus Jitu Membangun Pendidikan Karakter Pada Anak) (Kota Bru: Beta Asara, 2019). 
suatu perilaku yang berkenaan dengan orang tua dalam memengang posisi tertentu dalam lingkup keluarga yang didalmnya menjalankan peran sebagai pengasuh, pembimbing, dan pendidik bagi anak. ${ }^{28}$ Terdapat bermacam-macam jenis pola asuh yang dapat digunakan oleh orang tua. Berbagai macam pola asuh tersebut nantinya akan menghasilkan beragam bentuk kepribadian pada anak misalnya pola asuh otoriter akan menjadikan anak memiliki kepribadian phlegmatis, pola asuh demokratis akan melahirkan kepribadian asertif, begitu juga dengan pola asuh dan kepribadian lainnya. ${ }^{29}$

Anak-anak yang tumbuh dengan berbagai tekanan, misalnya rasa takut, khawatir, stress, dan sebagainya dapat berdampak tidak baik Ketika anak tersebut beranjak remaja. Ia akan merasakan suatu dorongan-dorongan agresif atau nakal yang menimbulkan efek negatif. Mungkin anak tersebut kreatif namun kreatifitas yang ia miliki ia salurkan pada hal-hal yang negatif. ${ }^{30}$ Dewasa ini jika membahas mengenai permasalahan pengasuhan anak, banyak sekali prasangka mengenai peran seorang ayah, banyak yang beranggapan bahwa hanya ibu yang memiliki tanggung jawab atas pengasuhan dan pendidikan anak. Hal tersebut merupakan pemikiran yang keliru, sebab secara umum kedua orang tua mempunyai peran yang sama pentingnya dalam pengasuhan anakanak mereka.

Ayah memiliki peran yang sama besarnya dengan ibu, tidak ada peran yang lebih besar karena keduanya memiliki porsi peran mereka masing-masing. Meskipun sederhana namun stigma tersebutlah yang membuat peran ayah di rumah jadi terlupakan. Padahal anak tidak hanya membutuhkan sosok ibu yang mendominasi namun juga sosok seorang ayah yang utuh. ${ }^{31}$ Namun, secara spesifik keduanya memiliki sentuhan peran yang berbeda. Adapun secara garis besar peran ibu adalah menumbuhkan rasa cinta dan kasih dalam diri anak melalui tindakan dan perilaku ibu yang penuh dengan kasih sayang, menumbuhkan keterampilan berbahasa anak dengan mengajaknya bercerita atau membacakannya dongeng, mengajarkan tata krama kepada anak.

Sedangkan peran ayah secara umum adalah menumbuhkan rasa percaya diri dan kompeten kepada anak dengan cara mengajaknya berkegiatan atau

\section{${ }^{28}$ Ibid.}

${ }^{29}$ Anggraini Anggraini, Pudji Hartuti, and Afifatus Sholihah, "Hubungan Pola Asuh Orang Tua Dengan Kepribadian Siswa Sma Di Kota Bengkulu," Consilia : Jurnal Ilmiah Bimbingan dan Konseling 1, no. 1 (2018).

30 Eli Rohaeli Badriah and Wedi Fitriana, "Pola Asuh Orang Tua Dalam Mengembangkan Potensi Anak Melalui Homeshooling Di Kancil Cendikia," Comm-Edu (Community Education Journal) 1, no. 1 (2018).

31 Dwi Citra Permatasari, Ayah Hebat = Anak Hebat (Yogyakarta: Anak Hebat Indonesia, 2021). 
bermain baik di dalam maupun di luar ruangan, menumbuhkan keinginan untuk berprestasi kepada anak dengan mengenalkannya pada berbagai macam citacita, mengajarkan anak untuk bertanggung jawab. ${ }^{32}$ Dalam buku yang berjudul Adolescence (perkembangan remaja) dijabarkan bahwa peran ibu identik dengan banyak hal positif, seperti kehangatan, tidak bersikap egois, bertanggung jawab dan toleran. Kebanyakan wanita mengharapkan perannya sebagai seorang ibu menyenangkan dan memuaskan. Namun pada kenyataannya memilih menjadi ibu dianggap sebagai prsestasi yang rendah di kalangan masyarakat, dihubungkan dengan uang, kekuasaan, dan prestasi. ${ }^{33}$

Menjadi ibu tidak menjanjikan hal-hal tersebut, malah sebaliknya para ibu jarang memperoleh penghargaan. Saat anak tidak berhasil atau membuat masalah, masyarakat cenderung menyalahkan ibu atas ketidakberhasilannya, padahal dalam psikologi dijelaskan bahwa kenakalan anak dapat disebabkan oleh berbagai faktor. Begitu pula dengan perkembangan anak, jadi ibu bukanlah satu-satunya penyebab hal tersebut terjadi. Pada kenyataannya walaupun ayah juga turut andil dan bertanggung jawab atas pengasuhan anak, namun tanggung jawab utama atas anak tersebut tetap berada pada pundak ibu.

Dalam satu studi remaja mengatakan bahwa ibu mereka lebih terlibat dalam pengasuhan dibandingkan ayahnya. Ibu melakukan pekerjaan rumah tangga dua hingga tiga kali lipat lebih banyak dibanding ayah, namun dalam satu studi dikatakan bahwa terdapat sekitar $10 \%$ pria yang melakukan pekerjaan rumah sama banyak seperti yang dilakykan istri. Karena pekerjaan rumah tangga berkaitan dengan rasa cinta dan kasih sayang yang terikat erat dalam hubungan keluarga, ia memiliki makna yang kompleks dan bertentangan. Para perempuan biasanya menikmati memenuhi kebutuhan orang yang mereka cintai dan mempertahankan jalannya keluarga walaupun kegiatan tersebut tidak bersifat menyenangkan dan memuaskan. ${ }^{34}$

Peran ayah mengalami perubahan-perubahan utama. Dahulu selama masa kolonial di Amerika, peran seorang ayah ialah memberikan pelajaran moral kepada sang anak. Hal ini terus berlanjut hingga the great depression. pada akhir perang dunia ke-II peran ayah bertambah, yaitu model peranan berdasarkan jenis kelamin. Kemudian pada tahun 1970-an barulah mulai muncul ketertarikan tentang ayah sebagai orang tua yang merawat dan memberikan perhatian kepada anak. Tidak hanya dalam bertanggung jawab

32 Twiningsih and H, Ayah Terlibat Keluarga Hebat (Jurus Jitu Membangun Pendidikan Karakter Pada Anak).

33 John W. Santrock, Perkembangan Remaja, ed. Shinto B. Adeler, Adolescenc. (Jakarta: Erlangga, 2003).

34 Ibid. 
terhadap disiplin dan pengendalian anak dan menyediakan keperluan ekonomi, kini peran ayah mulai dilihat dari bagaimana mereka merawat anak. ${ }^{35}$

Memiliki ayah dalam satu keluarga tidak menjamin akan adanya keterlibatan ayah dalam mengasuh anak, namun ada beberapa pengecualian di mana ayah menunjukkan komitmennya sebagai orang tua, sisanya adalah ayah yang asing bagi anaknya walaupun mereka tinggal dalam rumah yang sama. Ayah yang penyayang, menjalin komunikasi yang baik dengan anak, dan dapat diandalkan, yang mendorong kepercayaan dan keyakinan mampu mendorong tumbuh kembang anak dalam kehidupan bersosialnya. Dalam sebuah penyelidikan Frank Furstandberg dan Kathleen Harris (1992) melakukan dokumentasi pada ayah yang turut berperan dalam membesarkan anak.

Hal tersebut dapat membantu anak dalam melewati masa masa sulitnya. Kerja sama yang dilakukan oleh ayah dan ibu dapat membantu mengembangkan prilaku positif pada anak. Ketika kedua orang tua secara seimbang membagi tanggung jawab dalam membesarkan anak maka akan jauh lebih mudah saat menghadapi berbagai perubahan dalam keluarga. Saat kerja sama antara orang tua dibangun dengan baik maka tekanan yang dimiliki ibu menjadi lebih sedikit dan akan berdampak pada perilaku positif pada suami. ${ }^{36}$

Konstruksi sosial di masyarakat membuat orang tua membagi peran atas dasar jenis kelamin. Dalam konstruksi tersebut, ada kesepakatan tidak tertulis bahwa tugas suami adalah bekerja, dan tugas istri adalah mengurus rumah. Padahal antara ayah dan ibu harusnya berkolaborasi dalam rangka mendidik anak. Artinya urusan rumah tidak selalu menjadi tanggung jawab ibu, ayah juga dapat menjalanan tugas tersebut. kesalingan atau mubadalah ini sangat dimungkinkan berdampak bagi kesuksesan dalam memberikan pola asuh yang optimal.

\section{Konsep Mubadalah Faqihuddin Abdul Kodir dalam Pola Pengasuhan Anak}

Salah satu hal yang dapat menjadi penyebab terjadinya ketidakadilan gender di masyarakat adalah pendidikan pada keluarga. Pemilihan pola pengasuhan anak yang tidak merefleksikan kesetaraan dan keadilan gender dapat membentuk perilaku yang tidak responsif gender pada anak di kemudian hari. Karena sebagaimana yang diketahui Bersama bahwa Pendidikan keluarga adalah pondasi dasar dan yang paling utama dalam proses perkembangan anak. 
Pendidikan keluarga merupakan sarana anak untuk mulai mengetahui macam-macam gejala, baik yang dapat didengar, dilihat maupun dirasakan oleh anak. Berbagai hal dasar dapat terbentuk melalui pendidikan keluar seperti watak, akhlak, budi pekerti, kemampuan kognitif, sikap, dan berbagai aspek lain mulai terbentuk. ${ }^{37}$ Betapa pentingnya keluarga ini, maka pola asuh keluarga juga perlu diperhatikan dengan saksama, jangan sampai anak tumbuh dengan pola asuh yang mengkerdilkan gender tertentu karena kesalahan pola asuh keluarga.

Anak memiliki beberapa masa dalam perkembangan dirinya baik secara mental maupun fisik. masa-masa awal kehidupan anak adalah masa-masa yang sangat penting bagi prosese pertumbuhannya. Masa tersebut dikenal dengan sebutan golden age atau periode emas. Pertumbuhan dan perkembangan yang terjadi pada diri anak akan sangat berpengaruh terhadap pertumbuhan dan perkembangannya pada masa berikutnya. Dalam hal ini keluarga terutama orang tua sebagai lingkungan terdekat tempat anak belajar banyak hal memiliki peran penting untuk membantu tumbuh kembang anak. Menerapkan pola asuh yang baik dapat menjadi salah satu jalan bagi orang tua.

Islam juga memandang keluarga memiliki peran penting dalam dalam pendidikan anak baik dalam lingkungan keluarga muslim maupun non muslim. Sebab keluarga merupakan lingkungan pertumbuhan pertama bagi anak, dimana anak mendapatkan banyak pengaruh dari para anggota keluarga pada masa-masa golden age tersebut. Anak yang sholeh tidak dilahirkan secara alami. Anak-anak memerlukan bimbingan dan arahan secara berkesinambungan. ${ }^{38}$ Terdapat beberapa jenis pola pengasuhan anak, namun sebagaimana yang dijelaskan di atas, pola asuh yang sesuai dengan konsep mubadalah adalah pola asuh demokratis, yakni pola asuh yang menganggap bahwa kepentingan anak adalah hal yang paling penting, jadi orang tua memberikan kebebasan bgai anak untuk berkreasi namun tetap sesuai dengan batasan-batasan yang telah disepakati. Sehingga anak bertanggung jawab atas pilihannya dan paham akan konsekuensi yang akan dia dapatkan saat keluar dari jalur semestinya.

Pemilihan pola asuh menjadi suatu hal yang penting sebab baik buruknya perkembangan anak di masa mendatang tergantung pada pola asuh yang diterapkan oleh orang tua anak tersebut. Tentu saja dalam hal ini kedua orang tua baik ayah maupun ibu memiliki peran yang sama, keduanya harus memiliki relasi untuk saling bahu membahu bekerja sama dalam mendidik dan mengasuh

\footnotetext{
37 Misran Rahman, "Pendidikan Keluarga Berbasis Gender," Musawa 7, no. 2 (2015).

38 Mufaro'ah Ika Kurnia Sofiani, Titin Sumarni, "Bias Gender Dalam Pola Asuh Orangtua Pada Anak Usia Dini,” Jurnal Obsesi: Jurnal Pendidikan Anak Usia Dini 4 (2020).
} 
anak. Hal ini sesuai dengan konsep mubadalah yang berarti relasi yang terjadi antara dua orang yang mengandung nilai kerja sama, kesalingan yang terjadi dalam berbagai status sosial baik suami atau pun istri, orang tua dengan anak, dan lain sebagainya tanpa mengenal perbedaan gender.

Secara umum mubadalah merupakan suatu konsep mengenai kesetaraan gender dengan prinsip kesalingan dan relasi yakni sama-sama mendapatkan manfaat dari dua orang yang memiliki hubungan atau relasi. Jadi Perempuan ataupun laki-laki mempunyai hak dan kesempatan yang sama untuk berkecimpung di ranah publik maupun domestik, dan mengambil manfaat dari segala aspek kehidupan. ${ }^{39}$

Faqihuddin Abdul Kodir menawarkan konsep mubadalah (kesalingan). Konsep ini memegang prinsip setara, saling, sama, dan hal lainnya yang sejenis. ${ }^{40}$ Prinsip ini sebagai sebuah perspektif mudah diterima berbagai pihak, karena banyak ayat Alquran dan teks Hadis yang membicarakan hal ini. Pada area relasi pernikahan misalnya, banyak teks yang diinterpretasikan secara tidak adil; di mana satu pihak selalu menjadi subyek sementara yang lain lebih sering menjadi obyek, yang satu memperoleh kewajiban lebih banyak dari pihak lain, dan yang satu menjadi penyebab atas berbagai prahara rumah tangga sehingga harus selalu didisiplinkan. ${ }^{41}$

Penerapan konsep mubadalah dalam pola pengasuhan anak dapat diuraikan sebagai proses kerja sama antara ayah dan ibu dalam mengasuh anak. Tidak saling melimpahkan pekerjaan dan tanggung jawab pada satu sama lain. Di samping itu kedua orang tua harus memberikan kesempatan kepada anakanak mereka untuk melakukan berbagai permainan, dan pekerjaan tanpa melihat apakah permainan atau pekerjaan ini hanya boleh dimainkan oleh anak perempuan atau laki-laki saja. Memberikan kesempatan dan tanggung jawab yang sama bagi anak laki-laki atau pun perempuan. ${ }^{42}$

Selain itu, pembagian tugas domestik harus dilakukan secara adil dan disepakati Bersama, serta tidak boleh melihat unsur kelamin, misalnya anak perempuan hanya bertugas memasak, mengepel, dan kegiatan bersih-bersih lainnya, sedangkan laki-laki lebih pada mengecat, mengganti bola lampu, dan sebagainya.

${ }^{39}$ Werdiningsih, "Penerapan Konsep Mubadalah Dalam Pola Pengasuhan Anak."

${ }^{40}$ Kodir, Qiraah Mubadalah.

${ }^{41}$ Faqihuddin Abdul Kodir, "Mafhum Mubadalah: Ikhtiar Memahami Qur'an Dan Hadits Untuk Meneguhkan Keadilan Resiprokal Islam Dalam Isu-Isu Gender," Jurnal Islam Indonesia 6, no. 2 (2017).

42 Werdiningsih, "Penerapan Konsep Mubadalah Dalam Pola Pengasuhan Anak." 
Biasanya dalam keluarga pekerjaan-pekerjaan yang memeiliki kaitan dengan keterampilan, teknologi dan peralatan elektronik selalu memberikan tugas-tugas tersebut kepada anak laki-laki dibandingkan kepada anak perempuan. Sementara anak perempuan ditekankan pada tugas-tugas yang berkaitan semua hal yang berbau "care" seperti merawat, mengasuh, dan melayani. ${ }^{43}$ Padahal aspek yang ditekankan dalam pengembangan Pendidikan pada perempuan adalah meliputi unsur pengetahuan dan keterampilan sebagai dasar pengembangan diri. ${ }^{44}$ Jika perempuan diberi Batasan untuk belajar hal tertentu, maka pengembangan potensi yang ada pada perempuan juga akan terhambat. Itu sebabnya pola asuh menjadi penting.

Adanya kerjasama yang dilakukan secara sepadan dan adil antara ayah dan ibu juga antara anak laki-laki dan perempuan dalam menjalankan fungsi keluarga dengan cara membagi peran dan pekerjaan baik yang bersifat publik, domestik maupun sosial kemasyarakatan akan sangat membantu dalam proses penanaman mubadalah dalam keluarga. ${ }^{45}$ Dengan Kerjasama tersebut, maka akan mengurangi adanya Subordinasi/Penomorduaan, yaitu anggapan bahwa salah satu jenis kelamin lebih rendah atau dinomorduakan posisinya dibandingkan dengan jenis kelamin lainnya. ${ }^{46}$ Kemudian juga harus ada transparansi antara anggota keluarga agar timbul rasa saling percaya, saling membutuhkan, dan saling membantu ketika kesusahan. Proses tersebut akan melahirkan rasa saling menghormati. Dalam mubadalah, segala sesuatunya harus bersifat "saling", artinya mulai dari tugas domestis, social, penyampaian pendapat, dan beberapa hal lainnya adalah sama dan saling membutuhkan. Adanya kebebasan yang diberikan orang tua kepada anak saat mereka mengambil keputusan dapat mendorog terjalinnya sikap saling menghargai dan menghormati antara anggota keluarga. ${ }^{47}$

${ }^{43}$ Muhammad Aqibun Najih, “Gender Dan Kemajuan Teknologi: Pemberdayaan Perempuan Pendidikan Dan Keluarga," HARKAT: Media Komunikasi Islam 12, no. 2 (2017).

${ }^{44}$ Dewi Ratnawati, Sulistyorini, and Ahmad Zainal Abidin, "Kesetaraan Gender Tentang Pendidikan Laki-Laki Dan Perempuan," HARKAT: Media Komunikasi Gender 15, no. 1 (2019).

45 Abdul Aziz, "Relasi Gender Dalam Membentuk Keluarga Harmoni (Upaya Membentuk Keluarga Bahagia)," HARKAT: Media Komunikasi Islam Tentang Gebder dan Anak 12, no. 2 (2017).

46 Resti Fauziah, Nandang Mulyana, and Santoso Tri Raharjo, "Pengetahuan Masyarakat Desa Tentang Kesetaraan Gender," Prosiding Penelitian dan Pengabdian kepada Masyarakat 2, no. 2 (2015).

47 Dede Nurul Qomariah, "Persepsi Masyarakat Mengenai Kesetaraan Gender Dalam Keluarga," Jurnal Cendekiawan Ilmiah PLS 4, no. 2 (2019). 
Mubadalah percaya bahwa perempuan jika dibiasakan dengan pola asuh yang tepat, maka potensinya akan sama dengan lelaki, bahkan dalam bidang kepemimpinan. Adapun subtansi kepemimpinan menurut teori qira'ah mubadalah adalah kepemimpinan yang memberikan prioritas mendasar pada kerja sama, kebersamaan, kepercayaan, dan apresiasi. Kepemimpinan dapat menjadi salah satu wadah bagi tiap individu untuk mengembangkan potensi. Dalam Islam kepemimpinan yang baik yang berdasarkan misi rahmatan lil alamin dapat memberikan kemaslahatan bersama. ${ }^{48}$ Hubungan yang bersifat vertikal dalam keluarga yang memberikan posisi hirarki keluarga dengan sistem kekuasaan telah banyak menimbulkan konflik berkepanjangan dalam keluarga. Hubungan ini cenderung menumbuhkan sikap-sikap otoriter. Sebaliknya pendekatan dengan sifat companionship atau hubungan yang bersifat horizonal (tidak hierarkis) dalam keluarga lebih banyak memberikan kesempatan dalam pembagian peran yang seimbang antara laki-laki (anak dan ayah/suami) dan perempuan (anak dan ibu/istri).

Pola asuh mubadalah dengan pondasi aspirasi, kemampuan, kebutuhan khusus dari masing-masing individu yang berbeda dalam suatu keluarga dapat menstimulus tumbuhnya kesadaran kolektif antaranggota keluarga sehingga menguatkan fungsi-fungsi yang ada di dalam sistem keluarga. Apabila peran keluarga sebagai unit terkecil dalam sebuah negara sudah berjalan dengan baik, maka akan akan tumbuh anak-anak yang nantinya menjadi manusia yang berkualitas dan dapat memberikan kemaslahatan bagi kemajuan masyarakat dan negara.

Mubadalah berusaha menggiatkan perbedaan jenis kelamin antara lakilaki dan perempuan. Interaksi antara keduanya dipandang sebagai suatu Kerjasama untuk saling melengkapi dan mendampingi satu sama lain. ${ }^{49}$ Dengan demikian formulasi konsep mubadalah pada pola pengasuhan anak dapat dilakukan dengan cara kerja sama antara ayah dan ibu dalam mengasuh anak, memberikan didikan mengenai prinsip kesalingan antara anak laki-laki maupun perempuan untuk bersama-sama bermain, bekerja sama dalam membantu pekerjaan rumah, berdialog, dan kesempatan untuk mengutarakan pendapat.

48 Euis Nur Fu'adah Nugraheni and Yumidiana Tya, "Hadis Kepemimpinan Perempuan: Penerapan Metode Qira'ah Mubadalah," Malan: Journal of Islam and Muslim Society 2, no. 2 (2020).

49 P, "Qira' Ah Mubadalah Dan Arah Kemajuan Tafsir Adil Gender: Aplikasi Prinsip Resiprositas Terhadap Alquran Surah Ali Imran : 14." 


\section{Kesimpulan}

Orang tua mempunyai peran yang sangat penting dalam tumbuh kembang anak-anak. keduanya merupakan pondasi pendidikan pertama dan lingkungan belajar pertama bagi anak. Oleh karena itu sangat penting bagi keduanya untuk memilih pola asuh yang akan mereka terapkan dalam mengasuh anak. Dalam tulisan ini dijabarkan bagaimana penerapan konsep mubadalah atau kerja sama, dan relasi antar gender diterapkan dalam pola asuh anak. Hal ini menjadi penting mengingat banyaknya isu mengenai ketimbangan gender di masyarakat. konsep mubadalah ini dapat diterapkan dengan cara ayah dan ibu menjalin kerja sama dalam mengasuh dan mendidik anak tanda adanya istilah ibu lebih dominan dari ayah. Kemudian, keduanya memberikan kesempatan kepada anak untuk mengenal berbagai hal termasuk pekerjaan, aktivitas maupun permainan secara menyeluruh tanpa membedakan aktivitas ini hanya boleh dilakukan oleh anak laki-laki dan aktivitas ini hanya boleh dilakukan oleh anak perempuan. Hal ini sangat berguna dalam membentuk karakter anak di kemudian hari agar tidak memandang manusia berdasarkan gendernya.

\section{Bibliografi}

Aidah, Sitti Nur. Tips Menjadi Orang Tua Inspirasi Masa Kini. Yogyakarta: KKM Indonesia, 2020.

Anggoro, Taufan. “Konsep Kesetaraan Gender Dalam Islam.” Afkaruna 15, no. 1 (2019).

Anggraini, Anggraini, Pudji Hartuti, and Afifatus Sholihah. "Hubungan Pola Asuh Orang Tua Dengan Kepribadian Siswa Sma Di Kota Bengkulu." Consilia: Jurnal Ilmiah Bimbingan dan Konseling 1, no. 1 (2018).

Aziz, Abdul. "Relasi Gender Dalam Membentuk Keluarga Harmoni (Upaya Membentuk Keluarga Bahagia).” HARKAT: Media Komunikasi Islam Tentang Gebder dan Anak 12, no. 2 (2017).

Badriah, Eli Rohaeli, and Wedi Fitriana. "Pola Asuh Orang Tua Dalam Mengembangkan Potensi Anak Melalui Homeshooling Di Kancil Cendikia." Comm-Edu (Community Education Journal) 1, no. 1 (2018).

Boediarsih, Boediarsih, Zahroh Shaluhiyah, and Syamsulhuda Budi Mustofa. "Persepsi Remaja Tentang Peran Gender Dan Gender Seksualitas Di Kota Semarang." Jurnal Promosi Kesehatan Indonesia 11, no. 1 (2016).

Fakih, Mansor. Analisis Gender Dan Transformasi Sosial. Yogyakarta: Insist Press, 2020. 
Fauziah, Resti, Nandang Mulyana, and Santoso Tri Raharjo. "Pengetahuan Masyarakat Desa Tentang Kesetaraan Gender." Prosiding Penelitian dan Pengabdian kepada Masyarakat 2, no. 2 (2015).

Fayumi, Badriyah, Marzani Anwar, and Siti Musdah Mulia. Keadilan Dan Kesetaraan Gender Persepektif Islam. Jakarta: Tim Pemberdayaan Perempuan Bidang Agama, 2001.

Ika Kurnia Sofiani, Titin Sumarni, Mufaro'ah. "Bias Gender Dalam Pola Asuh Orangtua Pada Anak Usia Dini." Jurnal Obsesi : Jurnal Pendidikan Anak Usia Dini 4 (2020).

Kodir, Faqihuddin Abdul. "Mafhum Mubadalah: Ikhtiar Memahami Qur'an Dan Hadits Untuk Meneguhkan Keadilan Resiprokal Islam Dalam Isu-Isu Gender." Jurnal Islam Indonesia 6, no. 2 (2017).

-_—. Qiraah Mubadalah. Yogyakarta: IRCiSoD, 2019.

Najih, Muhammad Aqibun. "Gender Dan Kemajuan Teknologi: Pemberdayaan Perempuan Pendidikan Dan Keluarga." HARKAT: Media Komunikasi Islam 12, no. 2 (2017).

Ngewa, Herviana Muarifah. "Peran Orang Tua Dalam Pengasuhan Anak.” Ya Bunayya 1 (2019).

Nugraheni, Euis Nur Fu'adah, and Yumidiana Tya. "Hadis Kepemimpinan Perempuan: Penerapan Metode Qira'ah Mubadalah.” Malan: Journal of Islam and Muslim Society 2, no. 2 (2020).

Nurhaeni, Ismi Dwi Astuti. Kebijakan Publik Pro Gender. Surakarta: LPP UNS Dan UNS Press, 2009.

P, Anisah Dwi Lestari. “Qira ' Ah Mubadalah Dan Arah Kemajuan Tafsir Adil Gender: Aplikasi Prinsip Resiprositas Terhadap Alquran Surah Ali Imran : 14." Muasarah: Jurnal Kajian Islam KOntemporer 2, no. 1 (2020).

Permatasari, Dwi Citra. Ayah Hebat=Anak Hebat. Yogyakarta: Anak Hebat Indonesia, 2021.

Qomariah, Dede Nurul. "Persepsi Masyarakat Mengenai Kesetaraan Gender Dalam Keluarga." Jurnal Cendekiawan Ilmiah PLS 4, no. 2 (2019).

Rahman, Misran. "Pendidikan Keluarga Berbasis Gender.” Musawa 7, no. 2 (2015).

Rakhmawati, Istina. "Peran Keluarga Dalam Pengasuhan Anak." KONSELING RELIGI: Jurnal Bimbingan Konseling Islam 6 (2015).

Ratnawati, Dewi, Sulistyorini, and Ahmad Zainal Abidin. "Kesetaraan Gender Tentang Pendidikan Laki-Laki Dan Perempuan.” HARKAT: Media Komunikasi Gender 15, no. 1 (2019). 
192 | FOKUS: Jurnal Kajian Keislaman dan Kemasyarakatan, vol. 6, no. 2, 2021

Saeed, Abdullah. Al-Qur'an Abad 21; Tafsir Kontekstual. Terjemahan. Bandung: Mizan, 2016.

Santrock, John W. Perkembangan Remaja. Edited by Shinto B. Adeler. Adolescenc. Jakarta: Erlangga, 2003.

Sumar, Warni Tune. "Ilmplementasi Kesetaraan Gender Dalam Bidang Pendidikan." MUSAWA 7, no. 1 (2015).

Syafie, M Sahlah. Bagaimana Anda Mendidik Anak. Bogor: Ghalia Indonesia, 2002.

Twiningsih, Anik, and Fepi Trimurni H. Ayah Terlibat Keluarga Hebat (Jurus Jitu Membangun Pendidikan Karakter Pada Anak). Kota Bru: Beta Asara, 2019.

Werdiningsih, Wilis. "Penerapan Konsep Mubadalah Dalam Pola Pengasuhan Anak." Ijougs: Indonesian Journal of Gender Studies 1, no. 1 (2020). 